\title{
Antibacterial Resistance of Aeromonas Species Isolated from Fish and Water of Manzala Lake.
}

\author{
*Eid, H.M., **Zainab, I.S. ***Al-Shaimaa, T.H. \\ hamzaeidedu@yahoo.com-ziziibrahim@yahoo.com- \\ alshaymaatawfik@yahoo.com \\ * Department of Bacteriology, Immunology, Mycology - Faculty of \\ Veterinary Medicine, Suez Canal University. ** Department of Food \\ Hygiene, Animal Health Research Institute, Port Said Branch \\ *** Department of Bacteriology, Animal Health Research Institute, Port \\ Said Branch.
}

\begin{abstract}
A total of 70 Aeromonas isolates isolated from 100 Oreochromis niloticus, 100 Mugil cephalus and 50 water samples from El Gamil region in Manzala Lake were investigated for antibiotic susceptibility test to 14 different antimicrobial agents using disc agar diffusion method. All strains showed (100\%) sensitivity to norfloxacin and showed high sensitivity to cefotaxime (91.4\%), gentamycin (90\%), nalidixic acid (80\%), amikacin $(78.6 \%)$ and chloramphenicol (74.3\%). On the other hand, all tested isolates were resistant to ampicillin, erythromycin and penicillin and they exhibited high resistance rate to vancomycin (94.3\%) and doxycycline (91.4\%). Multiple antimicrobial resistance (MAR) index values of the tested isolates were higher than 0.2. They were $0.38,0.36,0.36$ and 0.37 for A. hydrophila, A. sobria, A. caviae and A. schubertii, respectively.
\end{abstract}

Key Words: Aeromonas spp., Antibiogram, Manzala Lake.

\section{Introduction}

Manzala Lake the biggest coastal lake in Egypt is a shallow brackish lake extending between the Damietta Nile River branch and the Suez Canal with a maximum length of $50 \mathrm{~km}$ along the Mediterranean coast (Ahmed et al., 2009). Domestic agricultural and industrial wastes are brought from urban centers along the lengths of main drains such as Bahr El Baqur drain through which more than $30 \%$ of the inflow passes to the lake (Hereher, 2014).

Aeromonads are considered as example of emerging bacterial pathogens and broadly distributed in the environment in several natural habitats such as soil, fresh and brackish water and sewage (Garibay et al., 2006).

The indiscriminate use of antimicrobials in aquaculture has been associated with increased levels of antibiotic resistance 
causing unwanted drug residues in aquaculture products and in the environment (Rahman et al., 2009). The development of resistance to antimicrobial agents in bacterial pathogens is a global public health concern (Chugh, 2008). Ubiquitous bacteria, which are fit for colonizing diverse water types, are of specific interest to assessing potential forms of antimicrobial resistance dissemination. Given their ubiquity in water environment and patterns of gained antimicrobial resistance, members of the genus Aeromonas are good examples of such bacteria (Igbinosa and Okoh, 2012).

Aeromonas spp. comprises an effective marker for monitoring antimicrobial resistance in aquatic environments (Usui et al., 2016). Increase antibiotic resistance among potentially pathogenic strains of Aeromonads, demonstrating an emerging potential health concern. (Amsaveni et al., 2014). Therefore, the present study aimed to investigate the resistance patterns of Aeromonas species isolated from Manzala Lake fish and water.

\section{Material and Methods}

\section{Samples:}

A total of 200 fish samples (100 Oreochromis niloticus and 100 Mugil cephalus) in addition to 50 water samples were collected from El Gamil region located in the eastern north corner of Manzala Lake during the period from June 2018 to November 2018. Samples were collected in a sterile container, labeled and transported in insulated ice-boxes with ice to Port Said laboratory for Food Hygiene, Bacteriology Unit for bacteriological examination.

Isolation and Identification of Aeromonas species from fish and water samples:

Samples were collected aseptically from fish and water for isolation of Aeromonas spp. according to APHA (1998) Fish and water samples were enriched in alkaline peptone water at $37^{\circ} \mathrm{C}$ for $24 \mathrm{hr}$. Enriched culture media were streaked on Aeromonas agar plates for Aeromonas isolation. Identification and biotyping of the isolates was carried out according to Aerokey II of Carnahan et al. (1991a).

Antimicrobial susceptibility tests of Aeromonas species isolates:

Isolated Aeromonas species were investigated for antibiotic susceptibility test to 14 different antimicrobial agents using disc agar diffusion method. Pure isolates were grown on nutrient agar plates for $18 \mathrm{~h}$ afterward 4-6 colonies were suspended in normal physiological saline and adjusted to turbidity of $0.5-\mathrm{M}$ McFarland standard. Subsequently, the isolate suspension was spread onto Muller Hinton agar plates. Plates were allowed to dry and impregnated with the appropriate antibiotic disks. Plates were incubated at $36{ }^{\circ} \mathrm{C}$ for $24 \mathrm{~h}$ after which zones of inhibition were measured and 
recorded (Igbinosa et al., 2013). The strains were characterized as sensitive, intermediate or resistive based on the diameter of the inhibition zones around the disc as described by NCCLS/CLSI (2007). The antibiotic discs used were: Amikacin (AK, $30 \mu \mathrm{g})$, Ampicillin (AM, 10 $\mu \mathrm{g})$, Cefotaxime (CTX, $30 \mu \mathrm{g})$,Chloramphenicol (C, $30 \mu \mathrm{g}$ ), Doxycycline (DO, $30 \mu \mathrm{g}$ ), Erythromycin (E, $15 \mu \mathrm{g})$, Gentamycin (CN, $10 \mu \mathrm{g})$, Nalidixic acid (NA, 30 $\mu \mathrm{g}$ ), Norfloxacin (NOR, 10 $\mu$ ), Oxytetracycline ( $\mathrm{T}$, $30 \mu \mathrm{g})$, Penicillin G (P, 10u), Polymexin-B (PB, 300u),
Trimethoprim + Sulphamethoxazole $(\mathrm{SXT}, 1.25+23.75 \mu \mathrm{g}) \quad$ and Vancomycin (VA, $30 \mu \mathrm{g}$ ).

Multiple Antibiotic Resistances (MAR) index:

Multiple antibiotic resistance index (Sarter et al., 2007):

The multiple antibiotic resistances (MAR) index of the bacterial isolates was calculated based on the following formula: MAR index $=$ $\mathrm{X} /(\mathrm{Y} \times \mathrm{Z})$

$\mathrm{X}=$ total antibiotic resistance cases.

$\mathrm{Y}=$ total antibiotic used in the study.

$\mathrm{Z}=$ total isolates.

\section{Results}

Table (1): Identified Aeromonas species recovered from fish and water samples from Manzala lake $(n=258)$ :

\begin{tabular}{|l|c|c|}
\hline \multicolumn{1}{|c|}{ Identified isolates } & No. & \% \\
\hline A. hydrophila & 125 & 48.45 \\
\hline A. sobria & 73 & 28.29 \\
\hline A. caviae & 50 & 19.38 \\
\hline A. schubertii & 10 & 3.88 \\
\hline Total isolates & 258 & 100 \\
\hline
\end{tabular}

$\%$ were calculated from the total number of isolates $(\mathrm{n}=258)$. 
Table (2): Antibiogram of Aeromonas species isolates recovered from Manzala lake fishes and water:

\begin{tabular}{|c|c|c|c|c|c|c|c|c|c|c|c|c|}
\hline \multirow{3}{*}{$\begin{array}{c}\text { Aeromonas } \\
\text { species/ } \\
\text { Antimicrobial } \\
\text { discs }\end{array}$} & \multicolumn{3}{|c|}{ A. hydrophila $(\mathrm{n}=20)$} & \multicolumn{3}{|c|}{ A. sobria $\mathrm{n}=(20)$} & \multicolumn{3}{|c|}{ A. caviae $\mathrm{n}=(20)$} & \multicolumn{3}{|c|}{ A. schubertii $\mathrm{n}=(\mathbf{1 0})$} \\
\hline & $\mathrm{S}$ & $\mathrm{I}$ & $\mathrm{R}$ & $\mathrm{S}$ & $\mathrm{I}$ & $\mathrm{R}$ & $\mathrm{S}$ & $\mathrm{I}$ & $\mathrm{R}$ & $\mathrm{S}$ & $\mathrm{I}$ & $\mathrm{R}$ \\
\hline & N. $(\%)$ & $\begin{array}{l}\mathrm{N} \\
.(\%) \\
\end{array}$ & $\begin{array}{l}\mathrm{N} . \\
(\%)\end{array}$ & $\begin{array}{l}\mathrm{N} . \\
(\%)\end{array}$ & $\begin{array}{l}\mathrm{N} . \\
(\%)\end{array}$ & $\begin{array}{l}\mathrm{N} . \\
(\%)\end{array}$ & $\begin{array}{l}\mathrm{N} . \\
(\%)\end{array}$ & $\begin{array}{l}\mathrm{N} . \\
(\%)\end{array}$ & $\begin{array}{l}\text { N. } \\
(\%)\end{array}$ & $\begin{array}{l}\text { N. } \\
(\%)\end{array}$ & $\begin{array}{l}\mathrm{N} \\
.(\%) \\
\end{array}$ & $\begin{array}{l}\mathrm{N} . \\
(\%)\end{array}$ \\
\hline $\begin{array}{c}\text { Amikacin } \\
(30 \mu \mathrm{g})\end{array}$ & $\begin{array}{c}16 \\
(80)\end{array}$ & $\begin{array}{c}4 \\
(20) \\
\end{array}$ & $\begin{array}{c}0 \\
(0)\end{array}$ & $\begin{array}{c}20 \\
(100)\end{array}$ & $\begin{array}{c}0 \\
(0)\end{array}$ & $\begin{array}{c}0 \\
(0)\end{array}$ & $\begin{array}{c}12 \\
(60)\end{array}$ & $\begin{array}{c}8 \\
(40) \\
\end{array}$ & $\begin{array}{c}0 \\
(0) \\
\end{array}$ & $\begin{array}{c}7 \\
(70) \\
\end{array}$ & $\begin{array}{c}3 \\
(30) \\
\end{array}$ & $\begin{array}{c}0 \\
(0) \\
\end{array}$ \\
\hline $\begin{array}{c}\text { Ampicillin } \\
(10 \mu \mathrm{g})\end{array}$ & $\begin{array}{c}0 \\
(0) \\
\end{array}$ & $\begin{array}{c}0 \\
(0) \\
\end{array}$ & $\begin{array}{c}20 \\
(100) \\
\end{array}$ & $\begin{array}{c}0 \\
(0) \\
\end{array}$ & $\begin{array}{c}0 \\
(0) \\
\end{array}$ & $\begin{array}{c}20 \\
(100) \\
\end{array}$ & $\begin{array}{c}0 \\
(0) \\
\end{array}$ & $\begin{array}{c}0 \\
(0) \\
\end{array}$ & $\begin{array}{c}20 \\
(100) \\
\end{array}$ & $\begin{array}{c}0 \\
(0) \\
\end{array}$ & $\begin{array}{c}0 \\
(0) \\
\end{array}$ & $\begin{array}{c}10 \\
(100) \\
\end{array}$ \\
\hline $\begin{array}{c}\text { Cefotaxim } \\
(30 \mu \mathrm{g})\end{array}$ & $\begin{array}{c}20 \\
(100) \\
\end{array}$ & $\begin{array}{c}0 \\
(0) \\
\end{array}$ & $\begin{array}{c}0 \\
(0) \\
\end{array}$ & $\begin{array}{c}18 \\
(90) \\
\end{array}$ & $\begin{array}{c}2 \\
(10) \\
\end{array}$ & $\begin{array}{c}0 \\
(0) \\
\end{array}$ & $\begin{array}{c}16 \\
(80) \\
\end{array}$ & $\begin{array}{c}4 \\
(20) \\
\end{array}$ & $\begin{array}{c}0 \\
(0) \\
\end{array}$ & $\begin{array}{c}10 \\
(100)\end{array}$ & $\begin{array}{c}0 \\
(0) \\
\end{array}$ & $\begin{array}{c}0 \\
(0) \\
\end{array}$ \\
\hline $\begin{array}{c}\text { Chloramphnicol } \\
(30 \mu \mathrm{g})\end{array}$ & $\begin{array}{c}18 \\
(90) \\
\end{array}$ & $\begin{array}{c}2 \\
(10) \\
\end{array}$ & $\begin{array}{c}0 \\
(0) \\
\end{array}$ & $\begin{array}{c}14 \\
(70) \\
\end{array}$ & $\begin{array}{c}6 \\
(30) \\
\end{array}$ & $\begin{array}{c}0 \\
(0) \\
\end{array}$ & $\begin{array}{c}12 \\
(60) \\
\end{array}$ & $\begin{array}{c}8 \\
(40) \\
\end{array}$ & $\begin{array}{c}0 \\
(0) \\
\end{array}$ & $\begin{array}{c}8 \\
(80) \\
\end{array}$ & $\begin{array}{c}2 \\
(20) \\
\end{array}$ & $\begin{array}{c}0 \\
(0) \\
\end{array}$ \\
\hline $\begin{array}{c}\text { Doxycycline } \\
(30 \mu \mathrm{g}) \\
\end{array}$ & $\begin{array}{c}0 \\
(0) \\
\end{array}$ & $\begin{array}{r}0 \\
(0) \\
\end{array}$ & $\begin{array}{c}20 \\
(100) \\
\end{array}$ & $\begin{array}{c}0 \\
(0) \\
\end{array}$ & $\begin{array}{c}4 \\
(20) \\
\end{array}$ & $\begin{array}{r}16 \\
(80) \\
\end{array}$ & $\begin{array}{c}0 \\
(0) \\
\end{array}$ & $\begin{array}{c}2 \\
(10) \\
\end{array}$ & $\begin{array}{c}18 \\
(90) \\
\end{array}$ & $\begin{array}{c}0 \\
(0) \\
\end{array}$ & $\begin{array}{c}0 \\
(0) \\
\end{array}$ & $\begin{array}{c}10 \\
(100) \\
\end{array}$ \\
\hline $\begin{array}{c}\text { Erythromycin } \\
(15 \mu \mathrm{g})\end{array}$ & $\begin{array}{c}0 \\
(0) \\
\end{array}$ & $\begin{array}{c}0 \\
(0) \\
\end{array}$ & $\begin{array}{c}20 \\
(100) \\
\end{array}$ & $\begin{array}{c}0 \\
(0) \\
\end{array}$ & $\begin{array}{c}0 \\
(0) \\
\end{array}$ & $\begin{array}{c}20 \\
(100) \\
\end{array}$ & $\begin{array}{c}0 \\
(0) \\
\end{array}$ & $\begin{array}{c}0 \\
(0) \\
\end{array}$ & $\begin{array}{c}20 \\
(100) \\
\end{array}$ & $\begin{array}{c}0 \\
(0) \\
\end{array}$ & $\begin{array}{c}0 \\
(0) \\
\end{array}$ & $\begin{array}{c}10 \\
(100) \\
\end{array}$ \\
\hline $\begin{array}{c}\text { Gentamycin } \\
(10 \mu \mathrm{g}) \\
\end{array}$ & $\begin{array}{r}18 \\
(90) \\
\end{array}$ & $\begin{array}{c}2 \\
(10) \\
\end{array}$ & $\begin{array}{c}0 \\
(0) \\
\end{array}$ & $\begin{array}{c}20 \\
(100) \\
\end{array}$ & $\begin{array}{c}0 \\
(0) \\
\end{array}$ & $\begin{array}{c}0 \\
(0) \\
\end{array}$ & $\begin{array}{r}16 \\
(80) \\
\end{array}$ & $\begin{array}{c}4 \\
(20) \\
\end{array}$ & $\begin{array}{c}0 \\
(0) \\
\end{array}$ & $\begin{array}{c}9 \\
(90) \\
\end{array}$ & $\begin{array}{c}1 \\
(10) \\
\end{array}$ & $\begin{array}{c}0 \\
(0) \\
\end{array}$ \\
\hline $\begin{array}{c}\text { Nalidixic acid } \\
\quad(30 \mu \mathrm{g})\end{array}$ & $\begin{array}{c}20 \\
(100) \\
\end{array}$ & $\begin{array}{c}0 \\
(0) \\
\end{array}$ & $\begin{array}{c}0 \\
(0) \\
\end{array}$ & $\begin{array}{c}12 \\
(60) \\
\end{array}$ & $\begin{array}{c}8 \\
(40) \\
\end{array}$ & $\begin{array}{c}0 \\
(0) \\
\end{array}$ & $\begin{array}{c}14 \\
(70) \\
\end{array}$ & $\begin{array}{r}6 \\
(30) \\
\end{array}$ & $\begin{array}{c}0 \\
(0) \\
\end{array}$ & $\begin{array}{c}10 \\
(100) \\
\end{array}$ & $\begin{array}{c}0 \\
(0) \\
\end{array}$ & $\begin{array}{c}0 \\
(0) \\
\end{array}$ \\
\hline $\begin{array}{l}\text { Norfloxacin } \\
\quad(10 \mu \mathrm{g})\end{array}$ & $\begin{array}{c}20 \\
(100) \\
\end{array}$ & $\begin{array}{c}0 \\
(0)\end{array}$ & $\begin{array}{c}0 \\
(0) \\
\end{array}$ & $\begin{array}{c}20 \\
(100) \\
\end{array}$ & $\begin{array}{c}0 \\
(0) \\
\end{array}$ & $\begin{array}{c}0 \\
(0) \\
\end{array}$ & $\begin{array}{c}20 \\
(100) \\
\end{array}$ & $\begin{array}{c}0 \\
(0)\end{array}$ & $\begin{array}{c}0 \\
(0) \\
\end{array}$ & $\begin{array}{c}10 \\
(100) \\
\end{array}$ & $\begin{array}{c}0 \\
(0) \\
\end{array}$ & $\begin{array}{c}0 \\
(0)\end{array}$ \\
\hline $\begin{array}{c}\text { Oxytetracycline } \\
(30 \mu \mathrm{g})\end{array}$ & $\begin{array}{c}12 \\
(60)\end{array}$ & $\begin{array}{c}6 \\
(30) \\
\end{array}$ & $\begin{array}{c}2 \\
(10) \\
\end{array}$ & $\begin{array}{c}8 \\
(40) \\
\end{array}$ & $\begin{array}{c}8 \\
(40) \\
\end{array}$ & $\begin{array}{c}4 \\
(20) \\
\end{array}$ & $\begin{array}{c}12 \\
(60) \\
\end{array}$ & $\begin{array}{c}4 \\
(20) \\
\end{array}$ & $\begin{array}{c}4 \\
(20) \\
\end{array}$ & $\begin{array}{c}5 \\
(50) \\
\end{array}$ & $\begin{array}{c}3 \\
(30) \\
\end{array}$ & $\begin{array}{c}2 \\
(20) \\
\end{array}$ \\
\hline Penicillin (10u) & $\begin{array}{c}0 \\
(0)\end{array}$ & $\begin{array}{c}0 \\
(0)\end{array}$ & $\begin{array}{c}20 \\
(100) \\
\end{array}$ & $\begin{array}{c}0 \\
(0)\end{array}$ & $\begin{array}{c}0 \\
(0)\end{array}$ & $\begin{array}{c}20 \\
(100) \\
\end{array}$ & $\begin{array}{c}0 \\
(0) \\
\end{array}$ & $\begin{array}{c}0 \\
(0)\end{array}$ & $\begin{array}{c}20 \\
(100) \\
\end{array}$ & $\begin{array}{c}0 \\
(0) \\
\end{array}$ & $\begin{array}{c}0 \\
(0)\end{array}$ & $\begin{array}{c}10 \\
(100)\end{array}$ \\
\hline $\begin{array}{l}\text { Polymixin-B } \\
\quad(300 u)\end{array}$ & $\begin{array}{c}10 \\
(50)\end{array}$ & $\begin{array}{c}6 \\
(30) \\
\end{array}$ & $\begin{array}{c}4 \\
(20) \\
\end{array}$ & $\begin{array}{c}12 \\
(60)\end{array}$ & $\begin{array}{c}6 \\
(30) \\
\end{array}$ & $\begin{array}{c}2 \\
(10)\end{array}$ & $\begin{array}{c}10 \\
(50) \\
\end{array}$ & $\begin{array}{c}8 \\
(40) \\
\end{array}$ & $\begin{array}{c}2 \\
(10) \\
\end{array}$ & $\begin{array}{c}6 \\
(60) \\
\end{array}$ & $\begin{array}{c}2 \\
(20) \\
\end{array}$ & $\begin{array}{c}2 \\
(20) \\
\end{array}$ \\
\hline $\begin{array}{l}\text { Trimethoprim + } \\
\text { Sulfamethaxzole } \\
(1.25+23.75 \mu \mathrm{g})\end{array}$ & $\begin{array}{c}14 \\
(70)\end{array}$ & $\begin{array}{c}6 \\
(30)\end{array}$ & $\begin{array}{c}0 \\
(0)\end{array}$ & $\begin{array}{c}16 \\
(80)\end{array}$ & $\begin{array}{c}4 \\
(20)\end{array}$ & $\begin{array}{c}0 \\
(0)\end{array}$ & $\begin{array}{c}14 \\
(70)\end{array}$ & $\begin{array}{c}6 \\
(30)\end{array}$ & $\begin{array}{c}0 \\
(0)\end{array}$ & $\begin{array}{c}5 \\
(50)\end{array}$ & $\begin{array}{c}5 \\
(50)\end{array}$ & $\begin{array}{c}0 \\
(0)\end{array}$ \\
\hline $\begin{array}{c}\text { Vancomycin } \\
(30 \mu \mathrm{g})\end{array}$ & $\begin{array}{c}0 \\
(0) \\
\end{array}$ & $\begin{array}{c}0 \\
(0) \\
\end{array}$ & $\begin{array}{c}20 \\
(100) \\
\end{array}$ & $\begin{array}{c}0 \\
(0) \\
\end{array}$ & $\begin{array}{c}0 \\
(0) \\
\end{array}$ & $\begin{array}{c}20 \\
(100) \\
\end{array}$ & $\begin{array}{c}0 \\
(0) \\
\end{array}$ & $\begin{array}{c}2 \\
(10) \\
\end{array}$ & $\begin{array}{c}18 \\
(90) \\
\end{array}$ & $\begin{array}{c}0 \\
(0) \\
\end{array}$ & $\begin{array}{c}2 \\
(20) \\
\end{array}$ & $\begin{array}{c}8 \\
(80) \\
\end{array}$ \\
\hline $\begin{array}{c}\text { Total resistance } \\
\text { Cases }\end{array}$ & & & 106 & & & 102 & & & 102 & & & 52 \\
\hline
\end{tabular}

$\%$ is calculated according to the total number of isolates

S: Sensitive

I: Intermediate sensitive

R: Resistant

$\mathrm{N}$ : Number 
Table (3): Patterns of antimicrobial phenotype of total Aeromonas isolates recovered from Manzala lake fish and water $(n=70)$.

\begin{tabular}{|c|c|c|c|c|c|c|}
\hline \multirow{2}{*}{ Antimicrobial agents } & \multicolumn{2}{|c|}{ Sensitive } & \multicolumn{2}{|c|}{ Intermediate } & \multicolumn{2}{|c|}{ Resistance } \\
\hline & No & $\%$ & No & $\%$ & No & $\%$ \\
\hline Amikacin $(30 \mu \mathrm{g})$ & 55 & 78.6 & 15 & 21.4 & 0 & 0 \\
\hline Ampicillin $(10 \mu \mathrm{g})$ & 0 & 0 & 0 & 0 & 70 & 100 \\
\hline Cefotaxim $(30 \mu \mathrm{g})$ & 64 & 91.4 & 6 & 8.6 & 0 & 0 \\
\hline Chloramphnicol $(30 \mu \mathrm{g})$ & 52 & 74.3 & 18 & 25.7 & 0 & 0 \\
\hline Doxycycline $(30 \mu \mathrm{g})$ & 0 & 0 & 6 & 8.6 & 64 & 91.4 \\
\hline Erythromycin $(15 \mu \mathrm{g})$ & 0 & 0 & 0 & 0 & 70 & 100 \\
\hline Gentamycin $(10 \mu \mathrm{g})$ & 63 & 90 & 7 & 10 & 0 & 0 \\
\hline Nalidixic acid ( $30 \mu \mathrm{g})$ & 56 & 80 & 14 & 20 & 0 & 0 \\
\hline Norfloxacin $(10 \mu \mathrm{g})$ & 70 & 100 & 0 & 0 & 0 & 0 \\
\hline Oxytetracycline $(30 \mu \mathrm{g})$ & 37 & 52.9 & 21 & 30 & 12 & 17.1 \\
\hline Penicillin (10u) & 0 & 0 & 0 & 0 & 70 & 100 \\
\hline Polymixin-B (300u) & 38 & 54.3 & 22 & 31.4 & 10 & 14.3 \\
\hline $\begin{array}{l}\text { Trimethoprim+Sulfamethaxzole }(1.25+23.75 \\
\mu \mathrm{g})\end{array}$ & 49 & 70 & 21 & 30 & 0 & 0 \\
\hline Vancomycin $(30 \mu \mathrm{g})$ & 0 & 0 & 4 & 5.7 & 66 & 94.3 \\
\hline
\end{tabular}

$\%$ is calculated according to total number of isolates $(\mathrm{n}=70)$

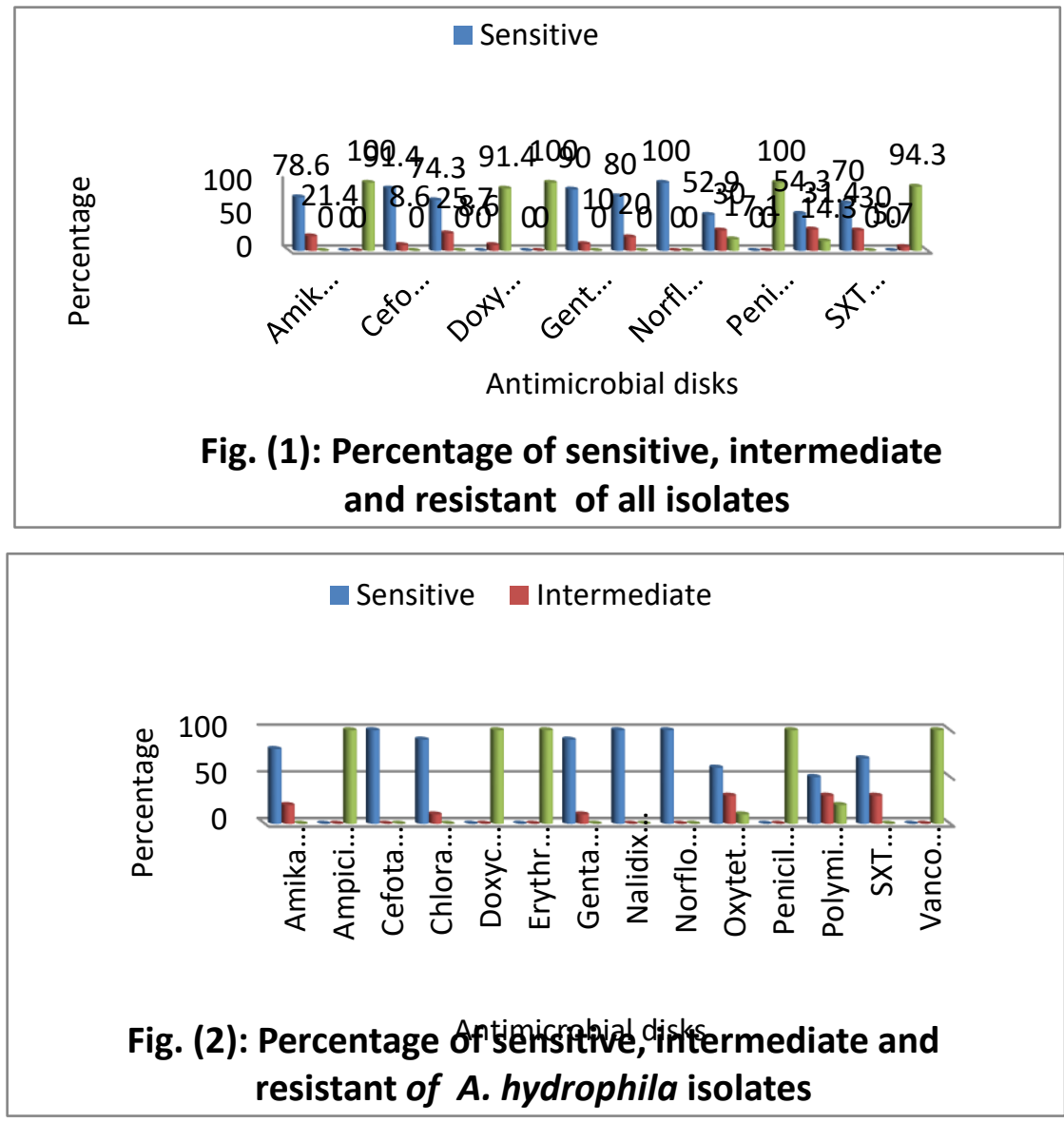




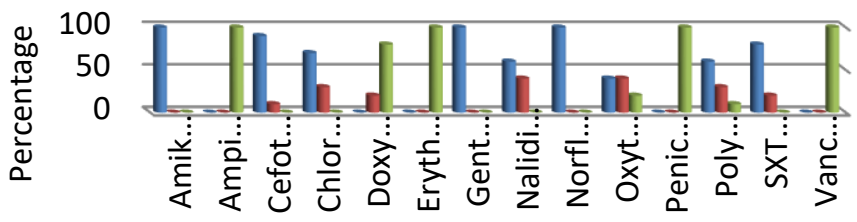

Antimicrobial disks

Fig. (3): Percentage of sensitive, intermediate and resistant of $A$. sobria isolates

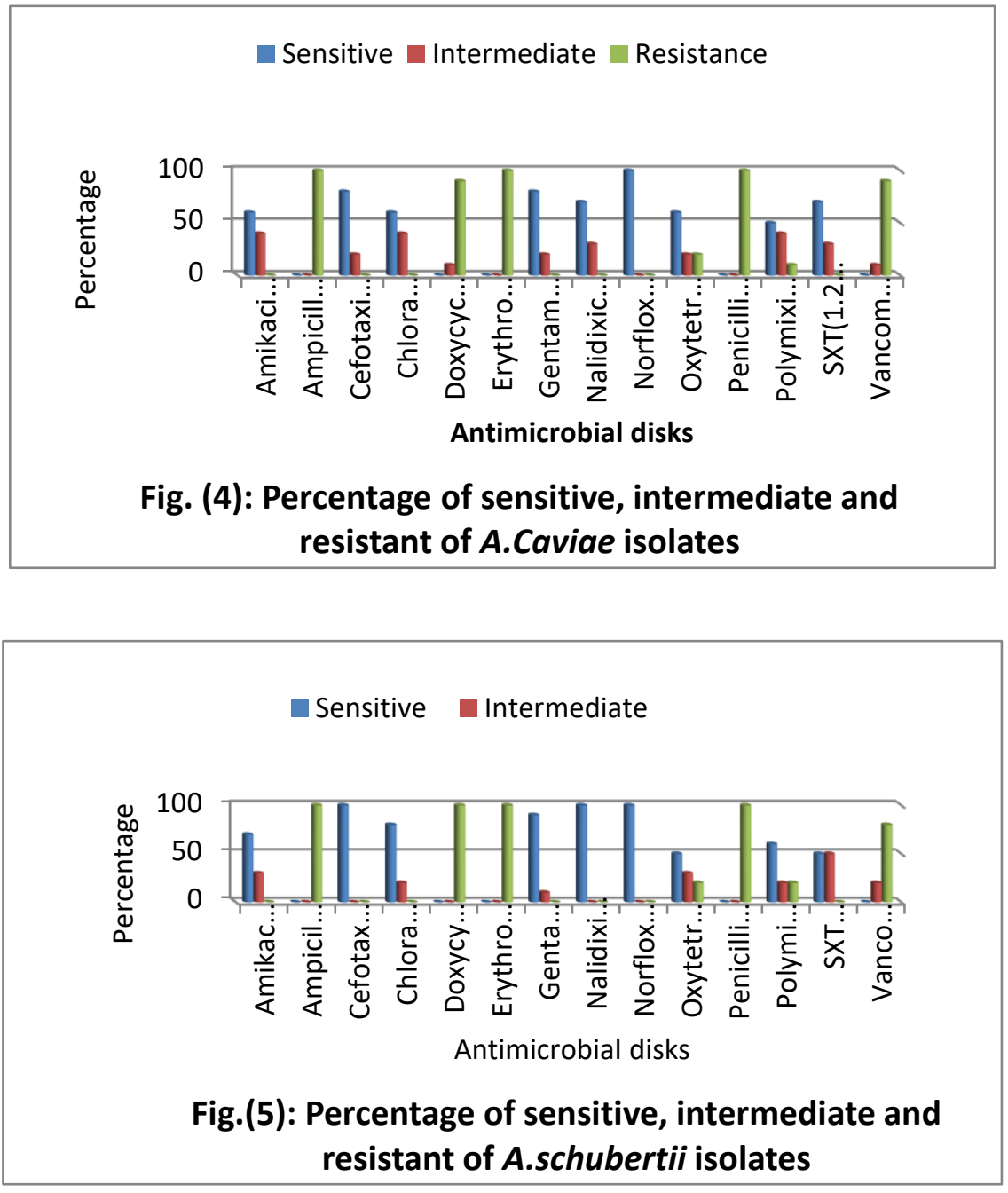


Table (4): MAR index and resistance patterns of the tested Aeromonas spp. isolates:

\begin{tabular}{|l|c|l|}
\hline Aeromonas spp. & Total number of antibiotic resistance cases & MAR index \\
\hline A. hydrophila & 106 & 0.38 \\
\hline A. sobria & 102 & 0.36 \\
\hline A. caviae & 102 & 0.36 \\
\hline A. schubertii & 52 & 0.37 \\
\hline
\end{tabular}

\section{Discussion}

The present result in Table (1) revealed that a total number of 258 isolates belonging to Aeromonas spp. were recovered from fishes and lake water samples and they were biochemically identified into 4 species (A. hydrophila, A. sobria, A. caviae and A. schubertii). 70 isolated Aeromonas species were selected for Antimicrobial susceptibility test to 14 different antibacterial agents.

Antibiogram and antimicrobial profiles of Aeromonas species isolates recovered from Manzala Lake fish and water were summarized in Table (2), (3) and graphically represented in Fig. (1). The present study revealed that all strains showed $(100 \%)$ sensitivity to Norfloxacin. Similar results were reported by Aravena et al. (2012) who found $100 \%$ sensitivity of Aeromonas spp. to norfloxacin. Also, high sensitivity to cefotaxime (91.4\%), gentamycin (90\%), nalidixic acid (80\%) and amikacin (78.6\%) were recorded. Furthermore, variable sensitivity of Aeromonas isolates to other antibiotics was observed which includes chloramphenicol (74.3\%), trimethoprim + sulphamethoxazole
(70\%), polymexin-B (54.3\%) and oxytetracycline $(52.9 \%)$. In this concern, Ko et al. (2003) recorded that Aeromonas spp. are sensitive to

cephalosporins, aminoglycosides, chloramphenicol, tetracycline, trimethoprimsulfametoxazole and fluoroquinolones. However, Petersen and Dalsgaard (2003) found that most of Aeromonas strains were resistant to the commonly used antibiotics such as chloramphenicol, tetracycline and trimethoprim.

Absolute resistance of isolated Aeromonas spp. to ampicillin, and penicillin was observed in the present study which may be attributed to $\beta$ - lactamase activity in the resistant isolates. The present findings agreed with Carnahan et al. (1991b) who mentioned that ampicillin resistance has been characteristic of genus Aeromonas. Additionally, Daood (2012) revealed that Aeromonas spp. were resistant to penicillins (penicillin, ampicillin, carbenicillin and ticarcillin), However, Stratev et al. (2013) found penicillin-sensitive strains. All tested strains showed (100\%) resistance to Erythromycin. Similar findings reported by 
Sreedharan et al. (2012) who reported that all Aeromonas isolates were resistant to erythromycin.

The present results indicated that there were a slight difference in antibiogram profiles and antimicrobial resistance pattern among Aeromonas species isolates as shown in Table (2), Fig. (2), (3), (4) and (5).

Concerning A. hydrophila isolates, results in Table (2) and Fig. (2) showed that isolates exhibited $(100 \%)$ sensitivity to cefotaxime, nalidixic acid and norfloxacin, also showed high sensitivity to chloramphenicol

$(90 \%)$, gentamycin (90\%), amikacin $(80 \%)$ and trimethoprim + sulphamethoxazole

$(70 \%)$.

Meanwhile, they were sensitive to moderately sensitive to, oxytetracycline $(60 \%)$ and polymexin-B (50\%). Our results agreed with Vila et al. (2002) who stated that all $A$. hydrophila isolates were highly sensitive to cefotaxime $100 \%$. They agreed with Kaskhedikar and Chhabra (2010) who reported that $A$. hydrophila showed $100 \%$ sensitivity to ciprofloxacin, cephotaxime, gentamycin and nalidixic acid, while $50 \%$ of the bacteria were susceptible to oxytetracycline. However, Guz and Kozinska (2004) found that all isolates of $A$. hydrophila were sensitive to trimethoprimsulfamide. Contrariwise Rawal et al. (2016) who reported that all $A$. hydrophila strains were found resistant to polymyxin $\mathrm{B}$, amikacin and trimethoprim.

The present results revealed that all A. hydrophila isolates were resistant to ampicillin (100\%), doxycycline $(100 \%)$, erythromycin (100\%), penicillin $\mathrm{G}(100 \%)$ and vancomycin $(100 \%)$. These results agreed with Awan et al. (2009) who indicated that $A$. hydrophila strains were $100 \%$ resist to ampicillin and vancomycin. Also, Vivekanandhan et al. (2002) observed resistance against erythromycin of more than $95 \%$ of A. hydrophila isolates. Meanwhile, Revina et al. (2017) found that $A$. hydrophila isolates were $(50 \%)$ resistance to doxycycline, contra wise Popovic et al. (2000) who found that $A$. hydrophila strains were sensitive to erythromycin.

Concerning A. sobria isolates, results in Table (2) and Fig. (3) revealed that $A$. sobria isolates showed (100\%) sensitivity to amikacin, gentamycin, and norfloxacin, also show high sensitivity to cefotaxime (90\%), trimethoprim + sulphamethoxazole (80\%) and chloramphenicol (70\%). Meanwhile, they were sensitive to moderately sensitive to nalidixic acid $(60 \%)$, polymexin-B $(60 \%)$ and oxytetracycline (40\%). This agreed with Awan et al. (2009) who demonstrated that $A$. sobria strains were sensitive to amikacin $100 \%$, gentamicin $100 \%$ and cefotaxime $100 \%$ although Wang and Silva (1999) isolated A. sobria 
strain sensitive to tetracycline $(100 \%)$ and trimethoprim + sulphamethoxazole (100\%). Contrariwise, Krovacek et al. (1992) who reported that A. sobria isolates were resistant to tetracycline and trimethoprim + sulphamethoxazole.

On the other hand, A. sobria isolates exhibited (100\%) resistance to ampicillin (100\%), erythromycin $(100 \%)$, penicillin $\mathrm{G}$ $(100 \%)$ and vancomycin $(100 \%)$ and exhibit high resistance to doxycycline (80\%). Our result agreed with Guz and Kozinska (2004) who reported that all $A$. sobria strains were resistant to ampicillin and penicillin, but less resistant to erythromycin (52\%).

Concerning to $A$. caviae, results in Table (2) and Fig. (4) revealed that isolates were $(100 \%)$ sensitive to norfloxacin, cefotaxime $(80 \%)$, gentamycin $(80 \%)$, nalidixic acid (70\%) and trimethoprim + sulphamethoxazole (70\%). Meanwhile, they were less sensitive to moderately sensitive to amikacin $(60 \%)$, chloramphenicol $(60 \%)$, oxytetracycline $(60 \%)$ and polymexin-B (50\%). Our results agreed with Vila et al. (2002) who revealed that $A$. caviae isolates were sensitive to nalidixic acid $74 \%$

trimethoprim/sulfamethoxazole

$79 \%$, but highly sensitive to cefotaxime $100 \%$, gentamicin $100 \%$, amikacin $100 \%$. On the other hand, Yucel et al. (2005) stated that $A$. caviae strains were resistant to trimethoprim, but less resistant to chloramphenicol.

All A. caviae isolates showed resistance to ampicillin (100\%), erythromycin (100\%) and penicillin $\mathrm{G}(100 \%)$ and exhibited high resistance to doxycycline $(90 \%)$ and vancomycin (90\%). These results were confirmed also by Daood (2012) who demonstrated that all $A$. caviae were resistant to ampicillin and penicillin, but Awan et al. (2009) reported that $A$. caviae strains were resistant to vancomycin (100\%), ampicillin $\quad(84.6 \%) \quad$ and erythromycin $(81.8 \%)$.

Concerning A. schubertii isolates, results in Table (2) and Fig. (5) revealed that all $A$. schubertii isolates $(100 \%)$ were sensitive to cefotaxime, nalidixic acid, norfloxacin, gentamycin (90\%), chloramphenicol (80\%) and amikacin (70\%). Meanwhile, they were less sensitive to moderately sensitive to polymexin-B (60\%), oxytetracycline $(50 \%)$ and trimethoprim + sulphamethoxazole (50\%). In this concept, Awan et al. (2009) found that $A$. schubertii strains were $(100 \%)$ sensitive to cefotaxim, gentamicin and (50\%) to trimethoprimsulfamethox and Liu and $\mathrm{Li}$ (2012) found that all $A$. schubertii isolates were susceptible to chloramphenicol, gentamicin, norfloxacin, oxytetracycline, sulfamethoxazole/trimethoprim.

On the other hand, all isolates were resistant to ampicillin, doxycycline (100\%), erythromycin (100\%), 
penicillin G (100\%), vancomycin (80\%), but showed less resistance (20\%) to oxytetracycline and polymexin-B. These results agreed with Awan et al. (2009) who revealed that all strains of $A$. schubertii were resistant to ampicillin and erythromycin.

Results in Table (4) revealed that the MAR index values of all isolates higher than 0.2 as they were $0.38,0.36,0.36$ and 0.37 for A. hydrophila, A. sobria, A. caviae and $A$. schubertii, respectively. These results agreed with Paul et al. (2015) who found the MAR index of Aeromonas spp. varied from 0.3 to 0.8 that indicated possible abuse of antibiotics. Also, Hossain et al. (2019) revealed that the MAR index values ranged from 0.19- 0.44 to $90.7 \%$ of Aeromonas isolates showed multidrug resistance.

MAR index exposes the spread of bacteria resistance in a given population. MAR index more than 0.2 indicates that the bacterial strain originates from an environment where many antibiotics are used (Ehinmidu, 2003) and thus posed health risk to human through the food chain. (Gwendelynne et al., 2005). In this study high incidence of multiple antibiotic resistances amongst Aeromonas species was detected suggesting presence of wastewater which acts as a reservoir of antibiotic resistance determinants. This become of particular importance especially with the increasing number of Aeromonas spp. infections and MDR strains that are spreading around the world (Batra et al., 2016).

In conclusion Manzala Lake is exposed to high inputs of pollutants from industrial, domestic, and agricultural sources so regular monitoring the prevalence of Aeromonas and spread of antibiotic resistance is particularly important especially with the increasing utilization of lake water to cultivated and fatten fish of various species. There are need to ensure that discharged final effluents of wastewater treatment plants are adequately treated to remove such pathogens as Aeromonas species to prevent the dissemination of multidrugresistant determinants into the receiving water bodies' environment.

\section{References:}

Ahmed, M.H.; El Leithy, B.M.; Thompson, J.R.; Flower, R.J.; Ramdani, M.; Ayache, F. and Hassan, S. (2009): Applications of remote sensing to site characterization and environmental change analysis of North African coastal lagoons. Hydrobiologia., 622(1):147-171.

Amsaveni, R.; Sureskkumar, M. and Vivekanandhan, G. (2014): Screening of pathogenic of Aeromonas species from marketed fish samples. International Journal 
of Pharmcy and Pharmaceutical Sciences, 6 (8): 148-150.

APHA (American Public Health Association)

(1998): Standard methods for examination of water and wastewater. $20^{\text {th }}$ ed. Washigton, DC, USA: American Public Health Association; 1998.

Aravena, R.M.; Inglis, T.J.J.; Henderson, B.; Riley, T.V. and Changa, B.J. (2012): Antimicrobial susceptibilities of Aeromonas strains isolated from clinical and environmental sources to 26 antimicrobial agents. Antimicrob. Agents. Chemother., 56:1110- 1112.

Awan, M.B.; Maqbool, A.; Bari, A. and Krovacek, K. (2009): Antibiotic susceptibility profile of Aeromonas spp. isolates from food in Abu Dhabi, United Arab Emirates. New Microbiologica., 32(1):17-23.

Batra, P.; Mathur, P. and Misra, M.C. (2016): Aeromonas spp.: an emerging nosocomial pathogen. J. Lab. Physicians., 8(1):1-4.

Carnahan, A.M.; Behram, S. and Joseph, S.W. (1991a): Aerokey II: a flexible key for identifying clinical Aeromonas species. Journal of Clinical Microbiology., 29: $2843-2849$.

Carnahan, A.M.; Chakraborty, T.; Fanning, G.R.; Verma, D.; Ali, A.; Janda, J.M. and Joseph, S.W. (1991b): Aeromonas trota sp. nov. an ampicillin- susceptible species isolated from clinical specimens. Journal Clinical Microbiology., 29: 1206-1210.
Chugh, T.D. (2008): Emerging and re-emerging bacterial diseases in India., J. Biosci., 33: 549-555.

Daood, N. (2012): Isolation and antibiotic susceptibility of Aeromonas spp. from freshwater fish farm and farmed farp (Dam of 16 Tishreen, Lattakia). Damascus Univ. J. Basic. Sci., 28: 27-39.

Ehinmidu, J.O. (2003): Antibiotics susceptibility patterns of urine bacterial isolates in Zaria, Nigeria., Trop. J. Pharm. Res., 2: 223-28.

Garibay, R.I.; Aguilera-Arreola, M.G.; Ocañia, A.N.; Cerezo, S.G.; Mendoza, M.S.; López, J.M.; Campos, C.E.; Cravioto, A. and Castro-Escarpulli, G. (2006): Serogroups, K1 antigen, and antimicrobial resistance patterns of Aeromonas spp. strains isolated from different sources in Mexico. Mem. Inst. Oswaldo Cruz., 101: 157-161.

Guz, L. and Kozinska, A. (2004): Antibiotic susceptibility of Aeromonas hydrophila and A. sobria isolated from farmed carp (Cyprinus carpio). Bull. Vet. Inst. Pulawy., 48: 391-395.

Gwendelynne, B.T.; Son, R.; Nishibuchi, M.; Raha, A.R.; Suhaimi, N. and Lesley, $M$. (2005): Characterization of Vibrio parahaemolyticus isolated from coastal seawater in Peninsular Malaysia. Southeast Asian J. Trop. Med. Pub. Health., 36: 940-945.

Hereher, M.H. (2014): The Lake Manzala of Egypt: an ambiguous 
future. Environ. Earth. Sci., 72: 1801- 1809.

Hossain, S.; Dahanayake, P.S.; DeSilva, B.C.; Wickramanayake, M.V.; Wimalasena, S.H. and Heo, G.J. (2019): Multidrug resistant Aeromonas spp. isolated from zebrafish (Danio rerio): antibiogram, antimicrobial resistance genes and class 1 integron gene cassettes. Lett. Appl. Microbiol., 68(5):370-377.

Igbinosa, I.H. and Okoh, A.I. (2012): Antibiotic susceptibility profile of Aeromonas species isolated from wastewater treatment plant. Sci. World J., 1-6.

Igbinosa, I.H.; Chigor, V.N.; Igbinosa, E.O.; Obi, L.C. and Okoh, A.I. (2013): Antibiogram, adhesive characteristics and incidence of class 1 integron in Aeromonas species isolated from two South African rivers. Biomed. Res. Int., Pp: 1-8.

Kaskhedikar, M. and Chhabra, D. (2010): Multiple drug resistance in Aeromonas hydrophila isolates of fish. Veterinary World., 3(2):76-77.

Ko, W.C.; Chiang, S.R.; Lee, H.C.; Tang, H.J.; Wang, Y.Y. and Chuang, Y.C. (2003): In vitro and in vivo activities of fluoroquinolones against Aeromonas hydrophila. Antimicrob. Agents Ch., 47: $2217-$ 2222.

Krovacek, K.; Faris, A.; Baloda, S.B.; Peterz, M.; Lindberg, T. and Ma ${ }^{\circ}$ nsson, I. (1992): Prevalence and characterization of
Aeromonas spp. isolated from foods in Uppsala, Sweden. Food Microbiol., 9:29-36.

Liu, J.Y. and Li, A.H. (2012): First case of Aeromonas schubertii infection in the freshwater cultured snakehead fish, Ophiocephalus argus (Cantor), in China. Journal of Fish Diseases., 35 (5): 335-342.

NCCLS/CLSI (National Committee for Clinical Laboratory Standards/ Clinical and Laboratory Standards Institute) (2007): CLSI document GP18-Laboratory design; approved guideline. $2^{\text {nd }}$ ed. Clinical and Laboratory Standards Institute, Wayne (PA); 2007.

Paul, P.; Adikesavalu, H.; Banerjee, S. and Abraham, T.J. (2015): Antibiotic resistant motile aeromonads induced septicemia in Philippine catfish Clarias batrachus $(L)$ fingerlings. Croatian Journal of Fisheries., 73(4): 170175.

Petersen, A. and Dalsgaard, A. (2003): Antimicrobial resistance of intestinal Aeromonas spp.

and Enterococcus spp. in fish cultured in integrated broiler-fish farms in Thailand. Aquaculture., 219(1-4):71-82.

Popovic, N.T.; Teskeredzic E.; Strunjakperovic, I. and CozRakovac, R. (2000): Aeromonas hydrophila isolated from wild freshwater fish in Croatia. Vet. Res. Commun., 24: 371-377.

Rahman, T.; Akanda, M.M.; Rahman, M.M and Chowdhury, M.B. (2009): Evaluation of the 
efficacies of selected antibiotics and medicinal plants on common bacterial fish pathogens. J. Bangladesh Agril. Univ., 7: 163168.

Rawal, I.; Joshi, H. and Chaudhary, B.L. (2016): Isolation, identification and antibiotics resistance of Aeromonas spp. from lakes of Udaipur (Rajasthan), India. Asian J. pharmaceutics., 10 (2):132-136.

Revina, O.; Avsejenko, J.; Cīrule, D. and Valciṇa, $O$. (2017): Antimicrobial resistance of Aeromonas spp. isolated from the sea trout (salmo trutta l.) in latvia. International Scientific

Conference: Research for Rural Development, Jelgava, Latvia., 1: 271-275.

Sarter, S.; Nguyen, H.N.; Hung, L.T.; Lazard, J. and Montet, D. (2007): Antibiotic resistance in Gram-negative bacteria isolated from farmed catfish. Food Control., 18: 1391-1396.

Sreedharan, K.; Philip, R.; Singh, B. and Sarojani, I. (2012): Virulence potential and antibiotic susceptibility pattern of motile Aeromonads associated with fresh water ornamental fish culture systems: A possible threat to public health. Braz. J. Microbiol., 43(2): 754-765.

Stratev, D.; Vashin, I. and Daskalov, H. (2013): Antimicrobial resistance of $\beta$ haemolytic Aeromonas hydrophila isolated from rainbow trouts (Oncorhynchus mykiss). Bulg. J. Vet. Med., 16: 289-296.

Usui, M.; Tagaki, C.; Fukuda, A.; Okubo, T.; Boonla, C. and Suzuki, S. (2016): Use of Aeromonasspp. as General indicators of antimicrobial susceptibility among bacteria in aquatic environments in Thailand. Front. Microbiol., 7:710.

Vila, J.; Marco, F.; Soler, L.; Chacon, M. and Figueras, $M$. (2002): In vitro antimicrobial susceptibility of clinical isolates of Aeromonas caviae, Aeromonas hydrophila and Aeromonas veronii biotype sobria. J. Antimicrob. Chemother., 49(4): 697-702.

Vivekanandhana, G.; Savithamania, K.; Hathab, A. and Lakshmanaperumalsamy, $P$. (2002): Antibiotic resistance of Aeromonas hydrophila isolated from marketed fish and prawn of South India. International Journal of Food Microbiology., 76 (1-2): 165-168.

Wang, C. and Silva, J. L. (1999): Prevalence and characterization of Aeromonas species isolated from processed channel catfish. J. Food Protect., 62: 30-34.

Yucel, N.; Aslim, B. and Beyatli, Y. (2005): Prevalence and resistance to antibiotics for Aeromonas species isolated from retail fish in Turkey. J. Food Quality., 28:313-324. 


\title{
المقاومة للمضادات البكتيرية لأنواع من الأيروموناس المعزولة من أسماك ومياه بحيرة المنزلة من الأيروت
}

\author{
*حمه محمد عيد **زينب إبراهيم سليمان ****الثيماء توفيق حنفي

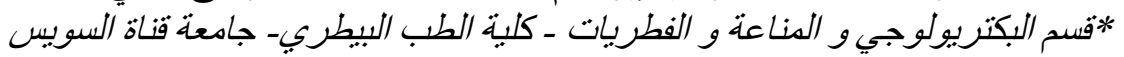

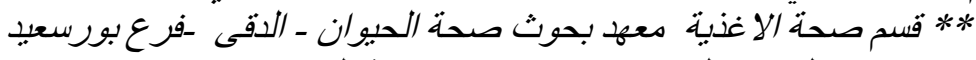

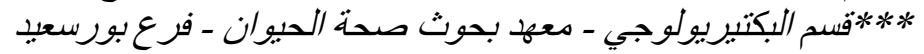

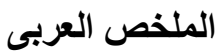

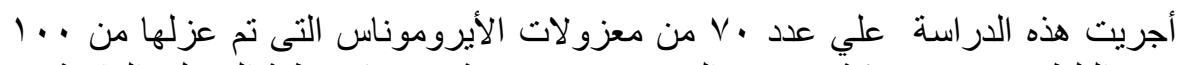

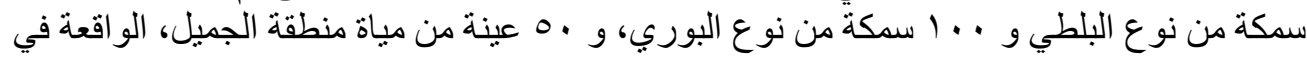

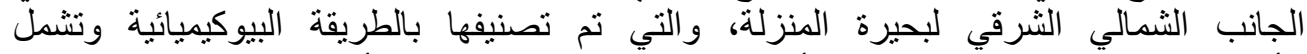

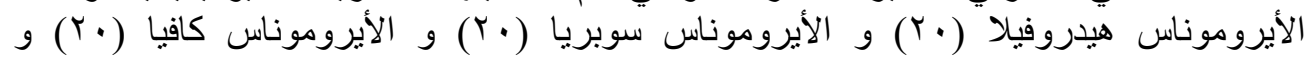

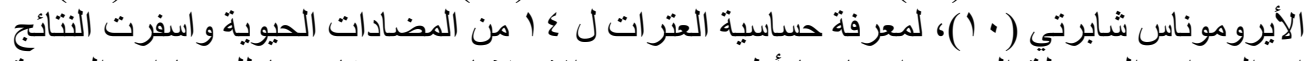

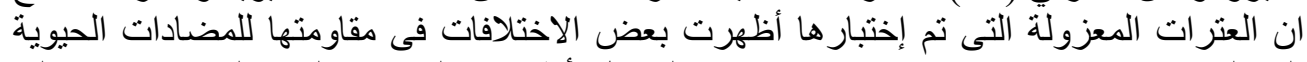

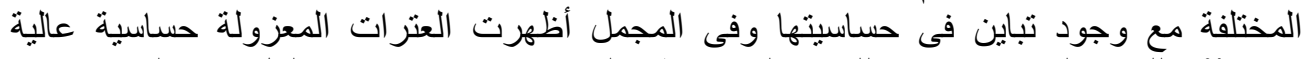

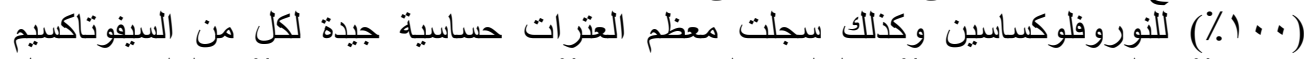

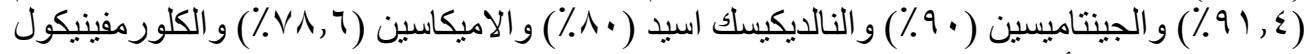

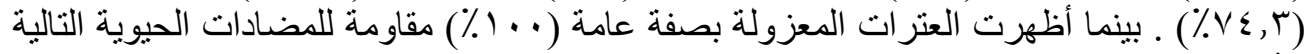

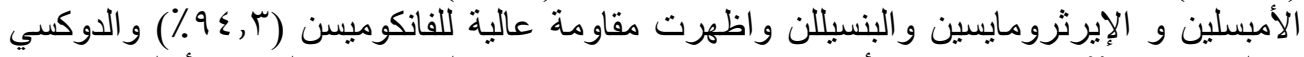

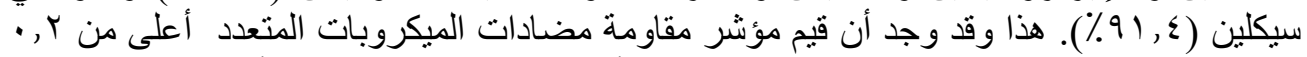

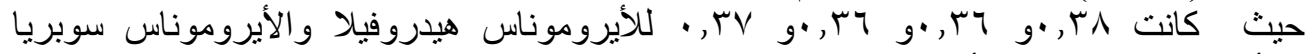
و الأيروموناس كافيا والأيروموناس شابرتي علي التوالي. مما يدل علي وجود هوني مقاومة متعددة 